\title{
Effects of ACTH and expression of the melanocortin-2 receptor in the neonatal mouse testis
}

\author{
Heather Johnston, Peter J King ${ }^{1}$ and Peter J O'Shaughnessy \\ Division of Cell Sciences, Institute of Comparative Medicine, University of Glasgow Veterinary School, Bearsden \\ Road, Glasgow G61 1QH, UK and ${ }^{1}$ William Harvey Research Institute, Molecular Endocrinology Centre, Bart's and \\ The London, Queen Mary, University of London, London EC1M 6BQ, UK
}

Correspondence should be addressed to PJ O’Shaughnessy; Email: p.j.oshaughnessy@vet.gla.ac.uk

\begin{abstract}
ACTH has been shown to stimulate androgen production by the fetal/neonatal mouse testis through the melanocortin type 2 receptor $(\mathrm{MC} 2 \mathrm{R})$. This study was designed to localize the expression of $M C 2 \mathrm{R}$ in the neonatal mouse testis and characterize the effects of ACTH on testicular androgen production. Using immunohistochemistry, MC2R was localized to the fetal-type Leydig cell population of the neonatal testis. ACTH caused a time-dependent increase in cyclic AMP (cAMP) and testosterone production by isolated cells with an increase in cAMP apparent in $<3 \mathrm{~min}$. There was no additive effect of maximally stimulating doses of ACTH and human chorionic gonadotropin (hCG). Androgen production in response to ACTH and hCG was reduced by UO126 and dexamethasone, which are the inhibitors of ERK1/2 and phospholipase A2 respectively. Expression of mRNA encoding StAR was increased fourfold by both ACTH and hCG, although expression of mRNA encoding for steroidogenic enzymes was not markedly affected. The potency of $\mathrm{N}$-terminal fragments of ACTH to stimulate androgen production was similar to that seen previously in the adrenal. Data indicate that both $\mathrm{LH}$ and $\mathrm{ACTH}$, acting through their respective receptors, stimulate steroidogenesis by fetal-type Leydig cells via arachidonic acid, protein kinase A, and ERK1/2 activation of StAR.
\end{abstract}

Reproduction (2007) 133 1181-1187

\section{Introduction}

Adrenocorticotropic hormone $(\mathrm{ACTH})$ regulates corticosteroid output from the adrenal cortex through interaction with the melanocortin type 2 receptor (MC2R). Outside of the adrenal cortex, MC2R expression has been described previously in murine adipocytes (Cammas et al. 1997) and we have shown recently that the receptor is also expressed in the mouse fetal testis (O'Shaughnessy et al. 2003). The testicular receptors appear to be functionally active since ACTH will stimulate testosterone production by the fetal and neonatal mouse testis which both contain fetal-type Leydig cells although the effects are lost in the postpubertal animal (O'Shaughnessy et al. 2003).

Androgen production by the fetal and neonatal mouse testis is dependent upon the fetal population of Leydig cells, which persists into early neonatal life and is responsive to luteinizing hormone $(\mathrm{LH}$; O'Shaughnessy et al. 2005). The effects of ACTH on fetal/neonatal androgen production could be directly mediated through melanocortin receptors on the fetal-type Leydig cells or indirectly mediated through another cell type. This second possibility is supported by the presence of paracrine factors in the fetal testis, which stimulate Leydig cell function (El-Gehani et al. 1998, 2001). This study was designed, therefore, to localize expression of $\mathrm{MC} 2 \mathrm{R}$ in the neonatal testis (which contains fetal-type Leydig cells) and, thereafter, to characterize the direct effects of ACTH stimulation of the testis.

\section{Materials and Methods \\ Animals}

Normal mice were bred at the University of Glasgow Veterinary School and maintained as required under United Kingdom Home Office regulations. The mice used were derived from $\mathrm{F} 1$ hybrids of $\mathrm{C} 3 \mathrm{H} / \mathrm{HeH}$ and $101 / \mathrm{H}$ strains. For all studies, the animals were aged 2 or 3 days after birth with the day of birth designated as day 1 .

\section{Cell isolation and incubation}

Dispersed testicular cells were prepared by collagenase treatment of whole testes as previously described (Stalvey \& Payne 1983). The testes from four to eight animals were dispersed at $37^{\circ} \mathrm{C}$ in DMEM/F12 
containing $1 \mathrm{mg} / \mathrm{ml}$ collagenase (Worthington CLS type 4, purchased from Lorne Laboratories Ltd, Twyford, UK; Stalvey \& Payne 1983) and isolated cells were filtered through a nylon sieve with a pore size of $50 \mu \mathrm{m}$. The proportion of Leydig cells in the cell preparations was $3-5 \%$ when tested by staining for $3 \beta$-hydroxysteroid dehydrogenase activity (Payne et al. 1980) although this parameter was not routinely measured in all samples. Aliquots of isolated cells ( $1 \mathrm{ml}$ total) were incubated for up to $18 \mathrm{~h}$ at $37^{\circ} \mathrm{C}$ in DMEM/F12 in an atmosphere of $5 \% \mathrm{CO}_{2}$ and in the presence of varying concentrations of human chorionic gonadotropin (hCG) or ACTH peptide fragments (Sigma-Aldrich Co Ltd). In experiments designed to measure cAMP production, isobutyl methyxanthine (Sigma-Aldrich) was included in the incubation medium at a concentration of $0.1 \mathrm{mM}$. In experiments to study the role of extracellular signal-regulated kinase ERK or arachidonic acid (AA) in the steroidogenic response to tropic hormone stimulation, the cells were preincubated for $30 \mathrm{~min}$ with UO126 (Calbiochem, Merck Biosciences Ltd, Nottingham, UK), which is a specific inhibitor of ERK (Davies et al. 2000) or dexamethasone, which is a phospholipase A2 $\left(\mathrm{PLA}_{2}\right)$ inhibitor (Blackwell et al. 1978). Tropic hormone was added after the preincubation period and the cells were incubated with inhibitor and hormone together for $3 \mathrm{~h}$.

At the end of the incubation period, cells and medium were placed in a heating block at $100{ }^{\circ} \mathrm{C}$ for 5 min and the medium collected after centrifugation at $4000 \mathrm{~g}$ for $10 \mathrm{~min}$. To measure the changes in gene expression, cells and medium were separated at the end of the incubation by centrifugation at $150 \mathrm{~g}$ and the cell pellet stored in liquid $\mathrm{N}_{2}$.

\section{RT and real-time PCR}

Total RNA was extracted using Trizol (Life Technologies). Isolated RNA was reverse transcribed using random hexamers and Moloney murine leukemia virus reverse transcriptase (Superscript II, Invitrogen) as described previously (O'Shaughnessy \& Murphy 1993, O'Shaughnessy et al. 1994).

To quantify the content of specific mRNA species in testicular cells following incubation in vitro with hCG or ACTH, a real-time PCR approach was used, which utilized the SYBR green method following RT of the isolated RNA. Real-time PCRs were performed in a 96-well plate format using a Stratagene MX3000 cycler. Reactions contained $5 \mu \mathrm{l}$ of $2 \times$ SYBR mastermix (Stratagene, Amsterdam, The Netherlands), primer $(100 \mathrm{nM})$, and template in a total volume of $10 \mu \mathrm{l}$. The thermal profile used for amplification was $95{ }^{\circ} \mathrm{C}$ for $8 \mathrm{~min}$ followed by 40 cycles of $95^{\circ} \mathrm{C}$ for $20 \mathrm{~s}, 63{ }^{\circ} \mathrm{C}$ for $20 \mathrm{~s}$, and $72{ }^{\circ} \mathrm{C}$ for $30 \mathrm{~s}$. At the end of the amplification phase, a melting curve analysis was carried out on the products formed. Negative controls without RNA were included in the RT and subsequent real-time PCR studies.

Primers for real-time PCR were designed using parameters previously described (Czechowski et al. 2004). The genes studied and primers used were:

Williams-Beuren syndrome chromosome region1 (WBscr1)

Forward agcatacggagtgtgtgcggctagtc

Reverse tcacccaagagtgcaccgtcataa

Cytochrome P450 side chain cleavage (Cyp11a1)

Forward cacagacgcatcaagcagcaaaa

Reverse gcattgatgaaccgctgggc

Cytochrome P450 17 -hydroxylase (Cyp17)

Forward tggtcccatctattctcttcgectg

Reverse aggcgacgccttttccttgg

Star

Forward cgtcggagctctctgcttggttc

Reverse tcgtcccottctcctgctg

Expression of each mRNA species was determined relative to the house-keeping gene $w b s c r 1$ as previously described (O'Shaughnessy et al. 2002).

\section{Immunohistochemistry}

Neonatal testes were fixed in $4 \%$ paraformaldehyde for $1 \mathrm{~h}$, then washed in $70 \%$ ethanol, dehydrated, and embedded in paraffin. Sections $(5 \mu \mathrm{m})$ were mounted on glass slides, dewaxed, and rehydrated. Endogenous biotin was blocked using an avidin/biotin blocking kit (R\&D systems Europe Ltd, Abingden, UK) and sections were incubated with primary antibody overnight at $4{ }^{\circ} \mathrm{C}$. The antibodies used were rabbit anti-mouse MC2R (Alpha Diagnostic, supplied by Autogen Bioclear, Calne, Wiltshire, UK) and rabbit anti-bovine CYP11A1 (gift from AH Payne). Sections were washed and incubated for $30 \mathrm{~min}$ with biotinylated secondary antibody (R\&D systems Europe Ltd). Bound antibody was visualized using 3,3-diaminobenzidine tetrahydrochloride (R\&D systems Europe Ltd). Negative controls without the primary antibody were included in each experiment.

\section{RIA}

Levels of testosterone in incubation medium were measured by RIA as previously described (O'Shaughnessy \& Sheffield 1990). Levels of cAMP were measured using a commercial assay system (Amersham Biosciences). 


\section{Statistical analysis}

Changes in CAMP levels over time were analyzed by one-tailed $t$-tests as basal levels were undetectable. Other statistical analysis was by two-factor ANOVA using log-transformed data followed by individual $t$-tests using the pooled error from the initial analysis.

\section{Results}

\section{Localization of MC2R expression in neonatal testis}

Using immunohistochemistry, expression of MC2R in the neonatal testis was limited to the interstitial tissue (Fig. 1A). Labeling of an adjacent section with the Leydig cell marker CYP11A1 indicated that the same cells were expressing both MC2R and CYP11A1 (Fig. 1B). A small number of cells appeared to express CYP11A1 but not $M C 2 R$ and this may be an indication that not all fetal-type Leydig cells express MC2R. All the cells expressing MC2R appeared to express CYP11A1. No immunohistochemical staining for MC2R was seen in the adult testis (not shown).

\section{Testicular response to $\mathrm{ACTH}$}

Incubation of isolated neonatal testicular cells with ACTH or hCG led to a time-dependent increase in testosterone production in response to both hormones (Fig. 2A). Responses to ACTH and hCG were identical up to $7 \mathrm{~h}$ and varied little up to $18 \mathrm{~h}$ (Fig. 2A). The response to $\mathrm{ACTH}$ was rapid with an increase in testosterone production seen within 5 min (Fig. 2B). Changes in CAMP levels in response to ACTH were also very rapid with an increase in cyclic nucleotide apparent within 3 min (Fig. 2C). To determine whether ERKs $1 / 2$ are involved in the steroidogenic response of fetal-type Leydig cells to ACTH and hCG cells were incubated with the specific inhibitor UO126. In the presence of UO126, there was a reduction in basal androgen production and
A

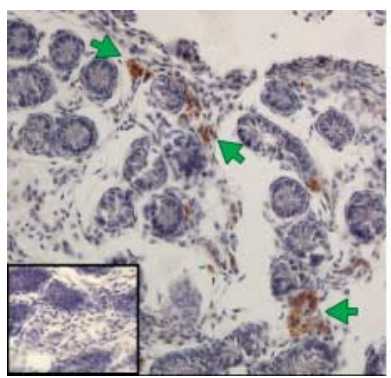

B

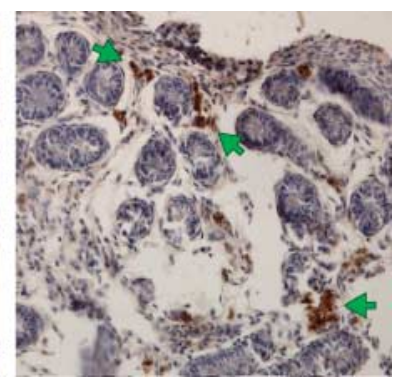

Figure 1 Immunohistochemical localization of (A) MC2R and (B) CYP11A1 in the neonatal testis. Adjacent sections of testes $(5 \mu \mathrm{m})$ from a neonatal mouse (day 2) were incubated with antibody to MC2R or CYP11A1 and visualized following binding to a biotinylated secondary antibody. Results show that the same cells in adjacent sections are stained with both antibodies (arrows). Control sections with no primary antibody did not show staining (inset to A).

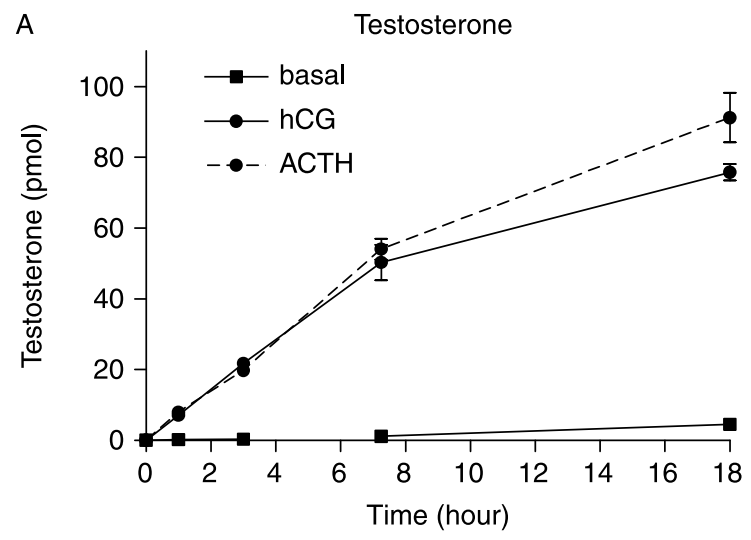

B
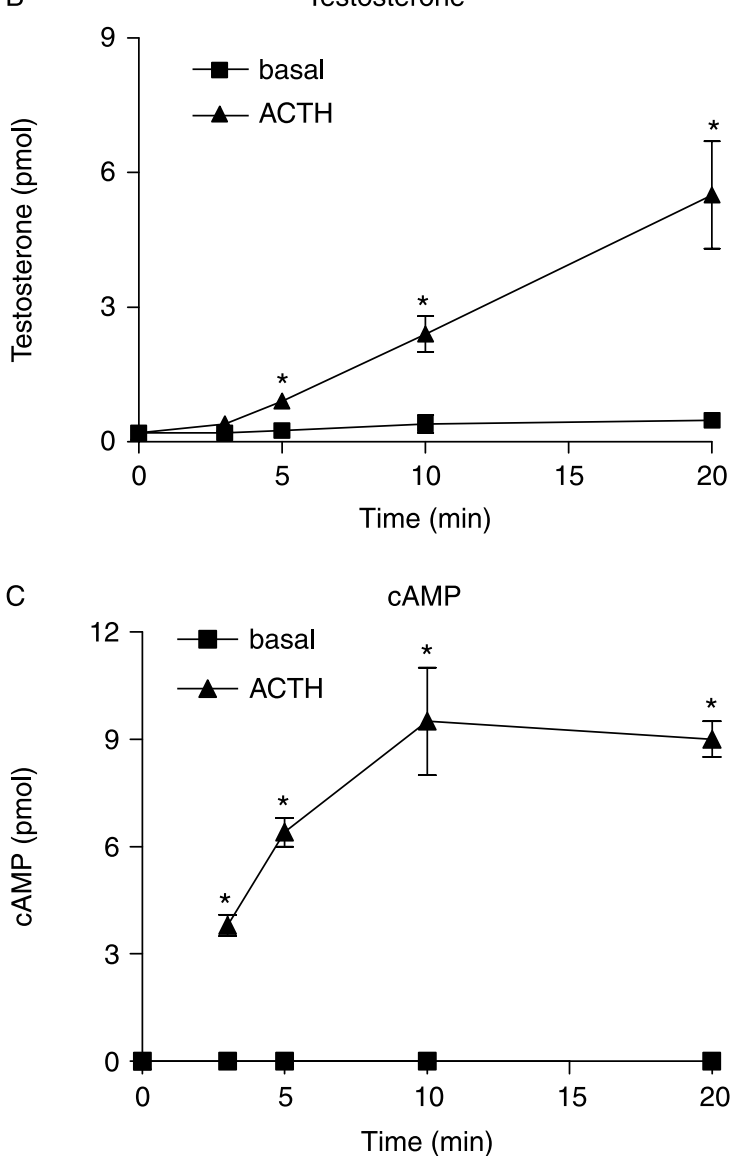

Figure 2 Time-dependent changes in testosterone and cAMP production by isolated cells from the neonatal testis in response to ACTH or hCG. Cells were isolated from neonatal testes and incubated with ACTH $\left(10^{-7} \mathrm{M}\right)$ or hCG $\left(10^{-9} \mathrm{M}\right)$. (A) Testosterone production during long-term incubation with ACTH or hCG. (B and C) Testosterone and CAMP production during short-term incubation in the presence of ACTH $\left(10^{-7} \mathrm{M}\right){ }^{*} P<0.05$ compared with basal level at same time. These studies have been repeated once.

both ACTH- and hCG-stimulated production were also significantly reduced (Fig. 3). The role of $\mathrm{PLA}_{2}$ in the steroidogenic response of cells to ACTH and hCG was measured using the $\mathrm{PLA}_{2}$ inhibitor dexamethasone 


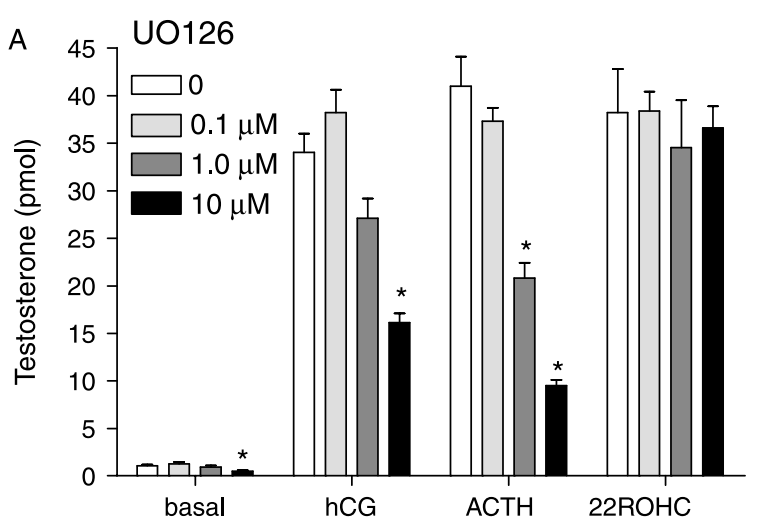

B Dexamethasone

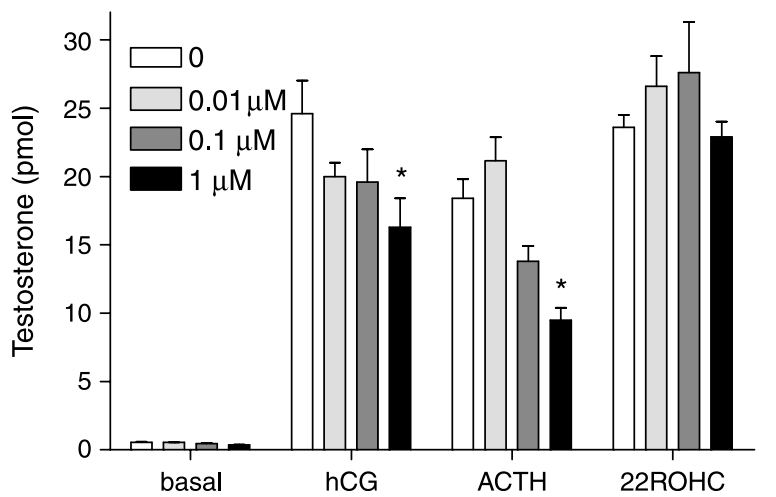

Figure 3 Effect of ERK1/2 and PLA2 inhibitors on ACTH-, hCG- and 22R-hydroxycholesterol (22ROHC)-stimulated testosterone production. (A) Cells isolated from neonatal testes were incubated, preincubated with the ERK1/2 inhibitor Uo126 (up to $10^{-5} \mathrm{M}$ ), and then stimulated with ACTH $\left(10^{-7} \mathrm{M}\right)$, hCG $\left(10^{-9} \mathrm{M}\right)$, or $22 \mathrm{R}$ hydroxycholesterol $(20 \mu \mathrm{M})$ for $3 \mathrm{~h}$. (B) Cells isolated from neonatal testes were preincubated with the PLA2 inhibitor dexamethasone (up to $10^{-6} \mathrm{M}$ ) and then stimulated with ACTH, hCG, or 22R-hydroxycholesterol as above. ${ }^{*} P<0.05$ compared with appropriate control. These studies have been repeated twice.

(Fig. 3). Basal steroidogenesis was not affected by dexamethasone although both ACTH- and hCG-stimulated production was inhibited at the highest dose of dexamethasone (Fig. 3). Steroidogenesis in the presence of 22R-hydroxycholesterol (22ROHC), which bypasses the second messenger systems to deliver cholesterol directly to the mitochondrion, was unaffected by the presence of UO126 or dexamethasone (Fig. 3).

\section{Effect of ACTH peptide fragments on Leydig cell steroidogenesis}

To determine whether the Leydig cell MC2R shows the same relative sensitivity to ACTH peptide fragments as the adrenal MC2R (Vinson et al. 1986, Hinson \& Birmingham 1987) neonatal testicular cells were incubated with ACTH (1-24), (1-17) and (1-16; Fig. 4A). The cells were most responsive to ACTH (1-24) with responsiveness to ACTH (1-17) and (1-16)
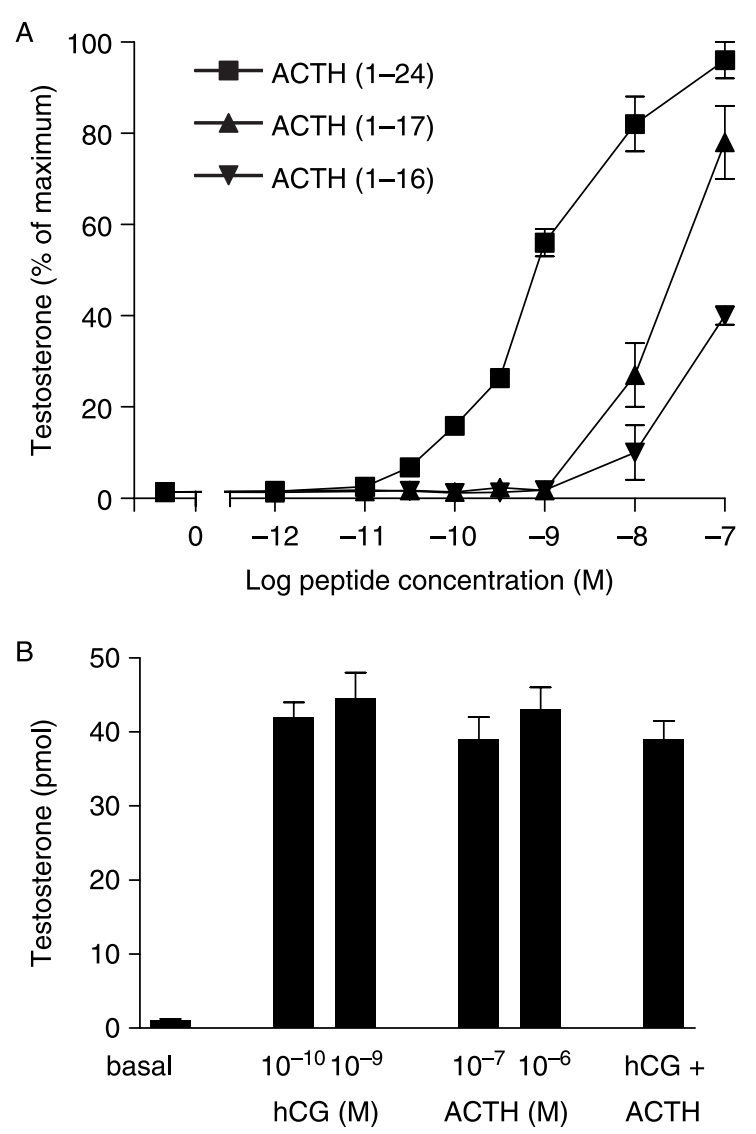

Figure 4 (A) Response of isolated testicular cells to different $\mathrm{N}$-terminal fragments of ACTH. Cells were incubated with ACTH fragments for $3 \mathrm{~h}$ and testosterone content of cells and medium measured by RIA. (B) Test for additive effects of hCG and ACTH. Neonatal cells were incubated with maximal concentrations of hCG $\left(10^{-9} \mathrm{M}\right)$, ACTH $\left(10^{-6} \mathrm{M}\right)$ or both together for $3 \mathrm{~h}$ and testosterone content of cells and medium measured by RIA. These studies have been repeated once.

about 100- and 1000-fold less respectively. Addition of maximally stimulating doses of both ACTH and hCG caused no further increase in testosterone production when compared with each hormone alone indicating that there was no apparent additive effect of the hormones once the cells were maximally stimulated (Fig. 4B).

\section{Acute effects of ACTH and hCG on fetal Leydig cell gene expression}

To determine whether hCG and ACTH stimulate similar changes in short-term gene expression in the neonatal testis, isolated cells were incubated with hCG or ACTH for $5 \mathrm{~h}$ and expression of three key Leydig cell genes measured. In cells incubated with ACTH or hCG, there was a small but significant increase in Cyp11a1 mRNA levels, no significant change in Cyp17 and a fourfold increase in Star mRNA levels (Fig. 5). There was no difference in the response of the cells to hCG or ACTH. 


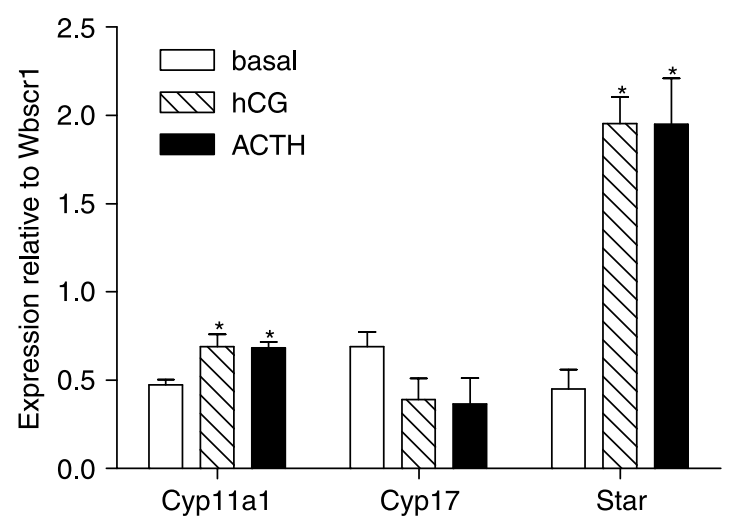

Figure 5 Early changes in gene expression in fetal Leydig cells stimulated by ACTH or hCG. Cells isolated from mouse neonatal testes were incubated under basal conditions or in the presence of ACTH $\left(10^{-7} \mathrm{M}\right)$ or hCG $\left(10^{-9} \mathrm{M}\right)$ for $3 \mathrm{~h}$. Expression of specific mRNA species was measured by real-time PCR as described in Materials and Methods. ${ }^{*} P<0.05$ compared with basal control.

\section{Discussion}

Five types of melanocortin receptor have been identified to date, each with characteristic affinity for the different melanocortins derived from proopiomelanocortin (Abdel-Malek 2001). In previous studies, we have shown that ACTH acts on the testis through MC2R (O'Shaughnessy et al. 2003) and the immunohistochemical data presented here show that MC2R expression is restricted to the interstitial tissue and to cells expressing CYP11A1. Since CYP11A1 expression in the testis is restricted to the Leydig cells (Wang et al. 2003), it is clear that MC2R is a Leydig cell product. It has been reported recently that MC2R is expressed in both the gonocytes and the interstitial tissue of the fetal mouse testis (Nimura et al. 2006). Our immunohistochemical and functional data agree with the interstitial localization of MC2R and suggest strongly that the Leydig cells are the site of interstitial expression. We did not, however, observe staining of MC2R in the germ cell component. There is no clear explanation for this discrepancy although the animals used in this study were about 3 days older than those used previously (Nimura et al. 2006) and it is possible that gonocyte expression is lost as the cells move into the neonatal phase of proliferation (Baker \& O'Shaughnessy 2001). Other studies have shown that $\mathrm{ACTH}$ can stimulate aromatase activity in neonatal Sertoli cells suggesting $\mathrm{MC} 2 \mathrm{R}$ could be expressed in these cells (Boitani et al. 1989). Sertoli cells were, however, equally responsive to other melanocortins ( $\alpha$-melanocyte-stimulating hormone $(\mathrm{MSH})$ and $\beta \mathrm{MSH})$ indicating that this effect is not mediated through MC2R but another melanocortin receptor (Abdel-Malek 2001).

During development, two populations of Leydig cells arise sequentially. The fetal-type Leydig cells arise soon after testis differentiation in the mouse and are subsequently replaced by the adult population, which starts to develop in the postnatal, prepubertal period (Baker et al. 1999, Nef et al. 2000). The adult Leydig cell population is primarily responsive to $\mathrm{LH}$ and, in the absence of $\mathrm{LH}$, cell numbers fail to develop and androgen production is minimal (Cattanach et al. 1977, Baker \& O'Shaughnessy 2001, Ma et al. 2004). The fetal Leydig cells are also responsive to LH but, unlike the adult population, $\mathrm{LH}$ is not essential for fetal Leydig cell development and function ( $\mathrm{O}^{\prime}$ Shaughnessy et al. 1998, Zhang et al. 2004). Results from this study now show that the fetal-type Leydig cells are also directly responsive to ACTH. In contrast, the postpubertal testis is not responsive to $\mathrm{ACTH}$ and $\mathrm{MC} 2 \mathrm{R}$ expression is minimal indicating that ACTH has no effect on the adult Leydig cell (O'Shaughnessy et al. 2003). In contrast to the mouse, earlier studies have reported that adult rabbit and guinea pig testes (but not rat, dog or hamster) will increase testosterone in response to ACTH (Juniewicz et al. 1988). This suggests that the adult Leydig cells may also express $M C 2 R$ in these species or there is persistence of significant numbers of fetal Leydig cells into the adult testes.

It is well established that CAMP is a critical second messenger in the LH-dependent stimulation of Leydig cell steroidogenesis. It has, for example, been shown that $\mathrm{LH} / \mathrm{hCG}$ causes rapid stimulation of cAMP production and that dibutyryl cAMP stimulates testosterone production through activation of StAR protein (Saez 1994, Stocco 2001). Results from this study show that ACTH causes a rapid stimulation of CAMP production within $3 \mathrm{~min}$ and before testosterone production is apparent. It is likely, therefore, that both $\mathrm{LH} / \mathrm{hCG}$ and ACTH stimulate steroidogenesis through CAMP-dependent pathways. It is known that cAMPactivates protein kinase $A$ (PKA), which in turn, activates StAR protein (Stocco 2001). Recent studies suggest, however, that cAMPactivation of ERK1/2 might also play a role in stimulation of adult Leydig cell steroidogenesis (Martinelle et al. 2004). Using the specific ERK inhibitor UO126, our data show that the transduction of signal from the LH-receptor or MC2R through the ERK cascade contributes to steroidogenic activity in the fetal mouse Leydig cell. Effects of UO126 were only seen at the higher concentrations of inhibitor, but this is similar to the effects of UO126 on rat Leydig cells (Martinelle et al. 2004) and reflects sensitivity of ERK1/2 to UO126 inhibition.

In addition to the pathways described above, there is also abundant evidence that AA can mediate tropic hormone signal transduction in steroidogenic cells (Stocco et al. 2005). Thus, G protein or cAMP can activate $\mathrm{PLA}_{2}$, which in turn, catalyzes AA release from phospholipids and leads to the activation of StAR (Wang et al. 2000). It has been shown that $\mathrm{LH}$ can induce $\mathrm{AA}$ release in rat Leydig cells and inhibition of AA release from phospholipids causes a marked inhibition of steroidogenesis (Abayasekara et al. 1990, Cooke et al. 1991). Our data 
using the $\mathrm{PLA}_{2}$ inhibitor dexamethasone show that a component of the stimulatory effect of $\mathrm{LH}$ and $\mathrm{ACTH}$ on androgen production by the fetal Leydig cells may be mediated through AA release from phospholipid. The effects on hCG- and ACTH-stimulation were, however, only seen at relatively high concentrations of inhibitor, higher than those required to show inhibition of steroidogenesis in MA-10 mouse Leydig tumor cells (Wang et al. 2000). Glucocorticoids can have direct inhibitory effects on Leydig cell steroidogenesis through the activation of the glucocorticoid receptor (Bambino \& Hsueh 1981, Hales \& Payne 1989), although this is unlikely in our studies because of the timescale of the effects and because steroidogenesis was normal in the presence of 22ROHC. Nevertheless, the relative insensitivity of fetal Leydig cells to dexamethasone may be an indication that the pathway through $\mathrm{PLA}_{2}$ is relatively minor in these cells.

In the adrenal, ACTH acts primarily through the stimulation of CAMP, PKA, and activation of StAR although there is good evidence that $\mathrm{ACTH}$ can act directly or downstream through the release of $\mathrm{AA}$ (Cooke 1999). There is also evidence of activation through ERK1/2 (Ferreira et al. 2004) although this pathway is less well documented in the adrenal. Activation of these pathways by ACTH in the fetal-type Leydig cells is, therefore, consistent with the effects of ACTH mediated through MC2R in the adrenal.

The signal pathways outlined above act to increase the activity of preformed StAR and also act to increase transcription of the Star gene (Stocco et al. 2005). Thus, increased expression of Star mRNA in neonatal mouse testis by hCG and ACTH is consistent with both hormones acting through similar signaling pathways in mouse fetal Leydig cells. It is known that LH acts to regulate and maintain expression of Cyp11a1 in the testis (Malaska \& Payne 1984, Mason et al. 1984, Scott et al. 1990) and studies using MA-10 cells have shown that the effects of LH can be rapid (Mellon \& Vaisse 1989). The effects of LH and ACTH on Cyp11a1 in the isolated testicular cells reported here are consistent, therefore, with these earlier studies. Expression of Cyp17 in the Leydig cell has also been shown to be regulated by LH (Anakwe \& Payne 1987, Baker et al. 2003) and the effects of CAMP on expression have been shown to be rapid in MA-10 cells (Laurich et al. 2002). It is not clear, therefore, why no increase in Cyp17 was seen in the present study although it is possible that increasing androgen levels in the medium may have inhibited Cyp17 expression (Hales et al. 1987).

Results from this study show that the fetal Leydig cells are responsive to both $\mathrm{LH}$ and $\mathrm{ACTH}$ and both hormones appear to act on the cell through similar mechanisms. In animals lacking either LH (or LH-receptor) or ACTH, fetal testosterone production is normal ( $\mathrm{O}^{\prime}$ Shaughnessy et al. 1998, 2003, Ma et al. 2004, Zhang et al. 2004) although studies using the T/erb-null mouse indicate that the fetal pituitary is required for normal fetal Leydig cell function (Pakarinen et al. 2002). It is possible, therefore, that $\mathrm{LH}$ and ACTH may act to regulate Leydig cell function in a redundant fashion.

\section{Acknowledgements}

This study was supported by the BBSRC. We thank Lynne Fleming for technical assistance. The authors declare that there is no conflict of interest that would prejudice the impartiality of this scientific work.

\section{References}

Abayasekara DR, Band AM \& Cooke BA 1990 Evidence for the involvement of phospholipase A2 in the regulation of luteinizing hormone-stimulated steroidogenesis in rat testis Leydig cells. Molecular and Cellular Endocrinology 70 147-153.

Abdel-Malek ZA 2001 Melanocortin receptors: their functions and regulation by physiological agonists and antagonists. Cellular and Molecular Life Sciences 58 434-441.

Anakwe OO \& Payne AH 1987 Noncoordinate regulation of de novo synthesis of cytochrome P-450 cholesterol side-chain cleavage and cytochrome P-450 17 alpha-hydroxylase/C17-20 lyase in mouse Leydig cell cultures: relation to steroid production. Molecular Endocrinology 1 595-603.

Baker PJ \& O'Shaughnessy PJ 2001 Role of gonadotrophins in regulating numbers of Leydig and Sertoli cells during fetal and postnatal development in mice. Reproduction 122 227-234.

Baker PJ, Sha JA, McBride MW, Peng L, Payne AH \& O'Shaughnessy PJ 1999 Expression of 3ß-hydroxysteriod dehydrogenase type I and VI isoforms in the mouse testis during development. European Journal of Biochemistry 260 911-916.

Baker PJ, Johnston H, Abel MH, Charlton HM \& O'Shaughnessy PJ 2003 Differentiation of adult-type Leydig cells occurs in gonadotrophin-deficient mice. Reproductive Biology and Endocrinology 14.

Bambino TH \& Hsueh AJ 1981 Direct inhibitory effect of glucocorticoids upon testicular luteinizing hormone receptor and steroidogenesis in vivo and in vitro. Endocrinology 108 2142-2148.

Blackwell GJ, Flower RJ, Nijkamp FP \& Vane JR 1978 Phospholipase A2 activity of guinea-pig isolated perfused lungs: stimulation, and inhibition by anti-inflammatory steroids. British Journal of Pharmacology 62 79-89.

Boitani C, Farini D, Canipari R \& Bardin CW 1989 Estradiol and plasminogen activator secretion by cultured rat Sertoli cells in response to melanocyte-stimulating hormones. Journal of Andrology 10 202-209.

Cammas FM, Pullinger GD, Barker S \& Clark AJ 1997 The mouse adrenocorticotropin receptor gene: cloning and characterization of its promoter and evidence for a role for the orphan nuclear receptor steroidogenic factor 1. Molecular Endocrinology 11 867-876.

Cattanach BM, Iddon CA, Charlton HM, Chiappa SA \& Fink G 1977 Gonadtrophin releasing hormone deficiency in a mutant mouse with hypogonadism. Nature 269 338-340.

Cooke BA 1999 Signal transduction involving cyclic AMP-dependent and cyclic AMP-independent mechanisms in the control of steroidogenesis. Molecular and Cellular Endocrinology 151 25-35.

Cooke BA, Dirami G, Chaudry L, Choi MS, Abayasekara DR \& Phipp L 1991 Release of arachidonic acid and the effects of corticosteroids on steroidogenesis in rat testis Leydig cells. Journal of Steroid Biochemistry and Molecular Biology 40 465-471. 
Czechowski T, Bari RP, Stitt M, Scheible WR \& Udvardi MK 2004 Realtime RT-PCR profiling of over 1400 Arabidopsis transcription factors: unprecedented sensitivity reveals novel root- and shoot-specific genes. Plant Journal 38 366-379.

Davies SP, Reddy H, Caivano M \& Cohen P 2000 Specificity and mechanism of action of some commonly used protein kinase inhibitors. Biochemistry Journal 351 95-105.

El-Gehani F, Zhang FP, Pakarinen P, Rannikko A \& Huhtaniemi I 1998 Gonadotropin-independent regulation of steroidogenesis in the fetal rat testis. Biology of Reproduction 58 116-123.

El-Gehani F, Tena-Sempere M, Ruskoaho H \& Huhtaniemi I 2001 Natriuretic peptides stimulate steroidogenesis in the fetal rat testis. Biology of Reproduction 65 595-600.

Ferreira JG, Cruz C, Vinson GP \& Pignatelli D 2004 ACTH modulates ERK phosphorylation in the adrenal gland in a time-dependent manner. Endocrine Research 30 661-666.

Hales DB \& Payne AH 1989 Glucocorticoid-mediated repression of P450scc mRNA and de novo synthesis in cultured Leydig cells. Endocrinology 124 2099-2104.

Hales DB, Sha LL \& Payne AH 1987 Testosterone inhibits cAMPinduced de novo synthesis of Leydig cell cytochrome P-450(17 alpha) by an androgen receptor-mediated mechanism. Journal of Biological Chemistry 262 11200-11206.

Hinson J \& Birmingham MK 1987 ACTH and adrenal aerobic glycolysis. II: effects of aminoterminal peptide fragments on lactic acid and steroid production by mouse adrenocortical cells. Journal of Endocrinology 115 71-76.

Juniewicz PE, Keeney DS \& Ewing LL 1988 Effect of adrenocorticotropin and other proopiomelanocortin-derived peptides on testosterone secretion by the in vitro perfused testis. Endocrinology 122 891-898.

Laurich VM, Trbovich AM, $\mathrm{O}^{\prime}$ Neill FH, Houk CP, Sluss PM, Payne AH, Donahoe PK \& Teixeira J 2002 Mullerian inhibiting substance blocks the protein kinase A-induced expression of cytochrome p450 17alpha-hydroxylase/C(17-20) lyase mRNA in a mouse Leydig cell line independent of cAMP responsive element binding protein phosphorylation. Endocrinology 143 3351-3360.

Ma X, Dong Y, Matzuk MM \& Kumar TR 2004 Targeted disruption of luteinizing hormone beta-subunit leads to hypogonadism, defects in gonadal steroidogenesis, and infertility. PNAS 101 17294-17299.

Malaska T \& Payne AH 1984 Luteinizing hormone and cyclic AMPmediated induction of microsomal cytochrome P-450 enzymes in cultured mouse Leydig cells. Journal of Biological Chemistry 259 11654-11657.

Martinelle N, Holst M, Soder O \& Svechnikov K 2004 Extracellular signal-regulated kinases are involved in the acute activation of steroidogenesis in immature rat Leydig cells by human chorionic gonadotropin. Endocrinology 145 4629-4634.

Mason JI, MacDonald AA \& Laptook A 1984 The activity and biosynthesis of cholesterol side-chain cleavage enzyme in cultured immature pig testis cells. Biochimica et Biophysica Acta 795 504-512.

Mellon SH \& Vaisse C 1989 cAMP regulates P450scc gene expression by a cycloheximide-insensitive mechanism in cultured mouse Leydig MA-10 cells. PNAS 86 7775-7779.

Nef S, Shipman T \& Parada LF 2000 A molecular basis for estrogeninduced cryptorchidism. Developmental Biology 224 354-361.

Nimura M, Udagawa J, Hatta T, Hashimoto R \& Otani H 2006 Spatial and temporal patterns of expression of melanocortin type 2 and 5 receptors in the fetal mouse tissues and organs. Anatomy and Embryology 211 109-117.

O'Shaughnessy PJ \& Murphy L 1993 Cytochrome P-450 17 $\alpha$ hydroxylase protein and mRNA in the testis of the testicular feminized (Tfm) mouse. Journal of Molecular Endocrinology 11 77-82.
O'Shaughnessy PJ \& Sheffield JW 1990 Effect of testosterone on testicular steroidogenesis in the hypogonadal ( $h p g)$ mouse. Journal of Steroid Biochemistry 35 729-734.

O'Shaughnessy PJ, Marsh P \& Dudley K 1994 Follicle-stimulating hormone receptor mRNA in the mouse ovary during post-natal development in the normal mouse and in the adult hypogonadal (hpg) mouse: structure of alternate transcripts. Molecular and Cellular Endocrinology 101 197-201.

O'Shaughnessy PJ, Baker P, Sohnius U, Haavisto A-M, Charlton HM \& Huhtaniemi I 1998 Fetal development of Leydig cell activity in the mouse is independent of pituitary gonadotroph function. Endocrinology 139 1141-1146.

O'Shaughnessy PJ, Willerton L \& Baker PJ 2002 Changes in Leydig cell gene expression during development in the mouse. Biology of Reproduction 66 966-975.

O'Shaughnessy PJ, Fleming LM, Jackson G, Hochgeschwender U, Reed P \& Baker PJ 2003 Adrenocoricotrophic hormone directly stimulates testosterone production by the fetal and neonatal mouse testis. Endocrinology 144 3279-3284.

O'Shaughnessy PJ, Baker PJ \& Johnston H 2005 Neuroendocrine regulation of leydig cell development. Annals of the New York Academy of Sciences 1061 109-119.

Pakarinen P, Kimura S, El-Gehani F, Pelliniemi LJ \& Huhtaniemi I 2002 Pituitary hormones are not required for sexual differentiation of male mice: phenotype of the T/ebp/Nkx2.1 null mutant mice. Endocrinology 143 4477-4482.

Payne AH, Downing JR \& Wong KL 1980 Luteinizing hormone receptors and testosterone synthesis in two distinct populations of Leydig cells. Endocrinology 106 1424-1429.

Saez JM 1994 Leydig cells: endocrine, paracrine, and autocrine regulation. Endocrine Reviews 15 574-626.

Scott IS, Charlton HM, Cox BS, Grocock CA, Sheffield JW \& O'Shaughnessy PJ 1990 Effect of LH injections on testicular steroidogenesis, cholesterol side-chain cleavage P450 messenger RNA content and leydig cell morphology in hypogonadal mice. Journal of Endocrinology 125 131-138.

Stalvey JR \& Payne AH 1983 Luteinizing hormone receptors and testosterone production in whole testes and purified Leydig cells from the mouse: differences among inbred strains. Endocrinology 112 1696-1701.

Stocco DM 2001 StAR protein and the regulation of steroid hormone biosynthesis. Annual Review of Physiology 63 193-213.

Stocco DM, Wang X, Jo Y \& Manna PR 2005 Multiple signaling pathways regulating steroidogenesis and StAR expression: more complicated than we thought. Molecular Endocrinology 19 2647-2659.

Vinson GP, Whitehouse BJ, Bateman A, Dell A \& Laird SM 1986 The actions of $\mathrm{N}$-terminal fragments of corticotrophin on steroidogenesis in dispersed rat adrenal cells in vitro. Journal of Endocrinology 109 275-278.

Wang X, Walsh LP, Reinhart AJ \& Stocco DM 2000 The role of arachidonic acid in steroidogenesis and steroidogenic acute regulatory (StAR) gene and protein expression. Journal of Biological Chemistry 275 20204-20209.

Wang GM, O'Shaughnessy PJ, Chubb C, Robaire B \& Hardy MP 2003 Effects of insulin-like growth factor I on steroidogenic enzyme expression levels in mouse leydig cells. Endocrinology 144 5058-5064.

Zhang FP, Pakarainen T, Zhu F, Poutanen M \& Huhtaniemi I 2004 Molecular characterization of postnatal development of testicular steroidogenesis in luteinizing hormone receptor knockout mice. Endocrinology 145 1453-1463.

Received 7 December 2006

First decision 2 February 2007

Accepted 22 February 2007 